\title{
The ethic of the free: A walk according to the Spirit! A perspective from Galatians
}

\author{
G M H Loubser ${ }^{1}$ \\ (University of Pretoria)
}

\section{ABSTRACT}

\section{The ethic of the free: A walk according to the Spirit! A perspective from Galatians}

The article argues that Galatians does not distinguish between soteriological and ethical freedom. Freedom encompasses the believer in Christ's entire salvation. However, he not only possesses freedom in Christ, but has to equally live it fully as a vocation. In as much as law has no salvational role in his life, it also has no ethical roll. The believer receives the Spirit by faith in Christ. The Spirit who quickens new life in him, orientating him to Christ, also guides and enables him to do God's will according to Christ's faithfulness. The latter is illustrated in His giving of Himself in loving service, even unto a cross, and so doing the will of our God and Father. The believer also glorifies God by doing his will in the loving and serving faithfulness of Christ, by the guidance of the Spirit. Thus, the believer's ethic of freedom is fully christological-pneumatological and anomistic without being libertinistic at all. Believers should not fear their God-given freedom by reverting to any form of law observance, but rather celebrate it by trustingly and freely walking in step with the Spirit.

\section{INTRODUCTION}

Paul's letter to the Galatians is bound to come into play in any discussion on Christian freedom. It is widely held as a most central witness to Christian freedom, undoubtedly so in Pauline theology. Sadly though, while this freedom is usually fully embraced at the soteriological level, it is not always met with the same enthusiasm at the ethical level - exactly the problem about which Paul is concerned in Galatians. He is convinced that soteriological freedom

\footnotetext{
1 The article is published as part of a Post-doctoral Fellowship Programme in the Department of NT Studies of the University of Pretoria. It is based on a section of a DD-dissertation: Ethics in the New Creation: a Celebration of Freedom! A Perspective from Paul's Letter to the Galatians, under supervision of Prof. J G van der Watt, and co-supervision of Prof. A B du Toit.
} 
must, as a matter of consequence, be translated into ethics. Ethics is the point where the truth of the gospel is put to the test, where theology and soteriology impact on daily living. Unfortunately, at this critical point many Christian scholars and laymen retract into a redefinition of freedom, unfamiliar to Galatians. When the ethical implications of Paul's concluding and celebratory exclamation at the end of his soteriological arguments ("For freedom Christ has set us free" - Gl 5:1) are considered, it is often hushed down to a cautionary whisper, as if one dare not practise one's freedom for fear of succumbing to flesh.

Many approach Galatians via Romans' seemingly more positive stance on law, assuming Paul rejected only part of law, or a certain attitude to it, but still regarded it as vital to Christian life. Some regard law's soteriological function as having been abolished, but given some distinctions and exclusions, not its ethical function. The issue is sometimes clouded when proponents for the ongoing validity of law seem not to have law as such in mind, but the need for Christians to hold high morals. However, I contend that, though Paul advocated high Christian morals, he did not equate morality with law observance, nor did he reintroduce a reduced or adapted canonical law.

\section{CALLED TO FREEDOM, BUT NOT THE FLESHLY KIND}

\subsection{The centrality of GI 5:13}

Readers of Galatians often jump from Galatians 5:1 to 5:13 ignoring everything in between. Equally, they ignore the strategic positions of the texts, the sections that they introduce, as well as the integrated and well-planned structure of the letter. It is wrong to assume that in Galatians 5:13 Paul subdues his exclamation on freedom in Galatians 5:1. It is equally wrong to regard Paul's enthusiastic reference to freedom in Galatians 5:1 as largely soteriological, and his reference in Galatians 5:13 as more ethical, and therefore,

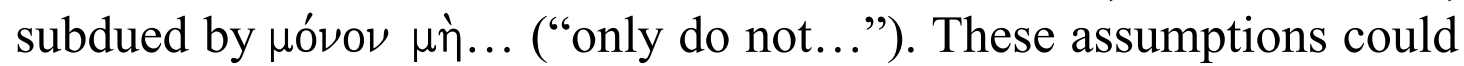
wrongly result in the notion that Paul was caught unawares by the implications of his arguments against law (Gl 1:11-4:31). Thus, so it is argued, after proclaiming the Christian's freedom (Gl 5:1); hitting the last nails into law's coffin; describing its observance as severance from Christ (Gl 5:2-4); and denouncing the Judaistic opposition (Gl 5:7-12), Paul suddenly realised that the believer's ethical flank had 
been left open to the threat of $\sigma \alpha \dot{\rho} \rho \xi$. Consequently, he was forced to add Galatians 5:13-6:10 as a cautionary against flesh.

I would argue that Paul was not caught unawares! His entire letter is an integrated unit throughout which $\sigma \alpha \dot{\alpha} \xi$ and $\pi \nu \in \hat{v} \mu \alpha$ fulfil a primary role. Paul was presented with a problem concerning circumcision, dietary and calendar laws. To his mind the implementation of any form of law threatened to ruin a much bigger picture (Gl 5:3). He was concerned that the Galatians had failed to understand the grandeur of the new dispensation or the profundity of the radical change introduced by the Christ event. Therefore, already in his introduction, Paul makes extremely significant remarks. Firstly, Christ's resurrection introduced the arrival of the long awaited, promised apocalyptic new aeon in which Israel's plight would be answered with God's solution. He would engrave his will in their hearts (Jr 31:33-34; Ezk 36:24-32) and pour his Spirit on them (J1 2:28-29). Secondly, his mission amounted to giving Himself "to deliver us (ő $\pi \omega \varsigma ~^{\prime} \xi^{\prime} \in \lambda \eta \tau \alpha \iota \dot{\eta} \mu \alpha \hat{\alpha}$ ) from the present evil age". He portrays Christ's advent as the hinge on which the door opened from

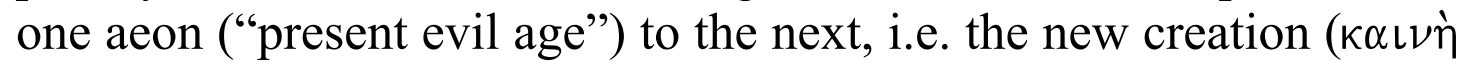

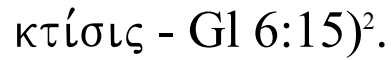

From the start (G1:4) Paul portrays soteriology as profoundly more than mere divine justification (G1 3:11) or redemption from the curse of law (G1 3:13). It is about deliverance from an age dominated by $\sin$ as a supra-human force, influencing, even enslaving man to act against God. It even proved law ineffective. In fact, law became slave to flesh. Paul emphasises the advent of a radically new situation. Salvation could not be obtained by law observance, only by being crucified with Christ and having new life in Him (Gl 2:1920). Equally, ethics in the new dispensation could not be defined by law. It would be contrary to believers' anomistic soteriological status. Not that the believer was now without sin. Although $\sigma \alpha \dot{\rho} \rho \xi$ had been dealt with in Christ and belonged to a bygone era, that era, although replaced in his advent, had not yet been displaced and its influence was identifiable in works of the flesh (Gl 5:19-21).

2 I do not share E P Sanders and the New Perspective's well-known view (see bibliography) that Paul moved from solution to plight. For refutations of the latter see Thielman (1989); Das (2001); Carson, O'Brien and Seifrid (2001). 
However, in Christ it could be withstood and life according to the Spirit could be chosen.

Paul's ethics is solidly founded on his theology and, in Galatians, specifically on his soteriology. The believer's ethics is no longer determined by law, but by being in Christ and walking in the Spirit. Morality is no longer measured by external codes, but by its portrayal of Christ's loving service on the cross. Law's restraints and limitations have made way for a creative ethic in which believers are given scope and responsibility to find their own ethical way characterised by love, guided by the Spirit, and assisted by the faith community.

\subsection{Flesh and law as bed mates}

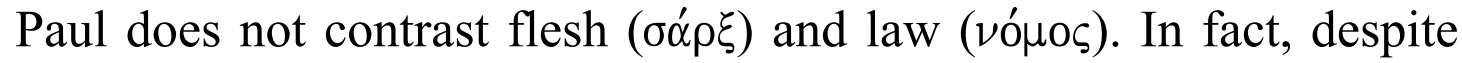
Yahweh's intentions, flesh actually employs law. They are not in opposition, but bed mates! According to Galatians 5:13f Paul portrays them as common enemies of the Spirit. This is emphasised for two reasons. Firstly, one should refrain from thinking in terms of two groups opposing Paul's gospel in Galatians. This is in direct conflict with the close relation Paul draws between flesh and law. One needs mention only Galatians 4:21-31 which explicitly aligns being under law (ن்ò vó $\mathrm{ov}_{\mathrm{O}}$ - Gl 4:21) with being born according to

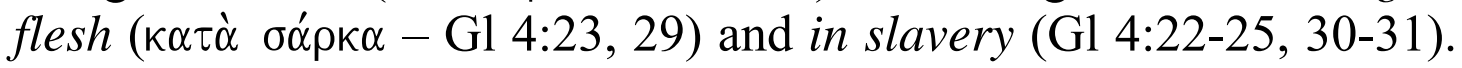
Equally, he aligns these in direct opposition to being born according

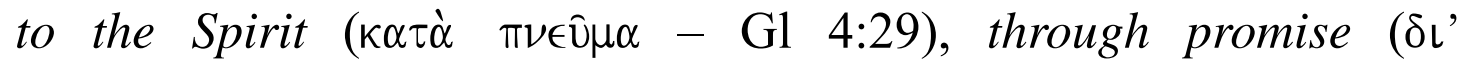
$\epsilon \pi \alpha \gamma \gamma \in \lambda i \alpha \varsigma$ - Gl 4:23, 28) and in freedom (Gl 4:22-23, 26, 30-31). The same can be said of Galatians 5:16-17 opposing Spirit and flesh, and G1 5:18, opposing Spirit and law. In the latter case Paul states: "But if you are led by the Spirit you are not under the law". The very reason for their not being under law was that they were no longer under flesh's slavery, but were walking according to the Spirit.

Secondly, if one were to assume that in Galatians 5 Paul turns away from law to address flesh, whether there really was an onslaught from a different party, or whether Paul merely feared the Galatians would allow the moral pendulum to swing from the ultraright law-observant position, through the so-called point of perfect equilibrium to the ultra-left amoral position, one would be in danger of considerably weakening Paul's argumentative section (G1 1:114:31) in which he refuted law-observance. He had died to law by being crucified with Christ (G1 2:19-20), who redeemed those under 
the law (G1 3:13). He delivered us from the present evil age (G1 1:4). Law was introduced 430 years after faith and only for the interim period up to the advent of Christ (Gl 3:15-20). With the advent of Christ and his Spirit the new age of freedom had dawned on believers (Gl 5:1). If Galatians 5:13-6:10 were to be read as a new theme, unconnected to the forgoing, one could get the impression that in the absence of law a new enemy, flesh, had arrived By implication, the reintroduction of a law or two would help against any licentiousness under duress of the flesh. This is tantamount to Paul advocating an ethical position at some or other point of equilibrium between law-observance and freedom, jeopardising freedom itself for fear of sinning.

Galatians 5:13-6:10 is not a cautionary against living Christian freedom. To the contrary, freedom is a vocation (Gl 5:13). Strictly speaking, it is not a warning against opening one's flanks to fleshly licentiousness. Galatians 5:13-24's primary function is to introduce the Spirit as the One who enables believers to live freely. It is about the role of the Spirit in Christians' lives - not about a void left by law's abolition. In any case, there is little evidence of law's success in dealing with flesh before or after the Christ event. It was positively about how to deal with the crucified flesh by the Spirit's guidance (G1 4:6).

In short, the flesh-law alliance cannot be severed, least of all in the ethical section. Following his exclamation (Gl 5:1), Paul explains how to stand firm (Gl 5:13-24). One does this in christological freedom by walking according to the Spirit (Gl 5:16) and producing his fruit, not by reintroducing law (Loubser 1994:169). Significantly, he introduces his ethical section proper reminding believers of their vocation to freedom (Gl 5:13) (Jones 1987:102). It is a banner spread across his exhortations: Remember your freedom! Practise it!

\subsection{Called to freedom}

After briefly digressing (Gl 5:2-12) Paul returns to freedom in Gl $5: 13^{3}$. One could visualise the enslaving present evil age occupying centre-stage until Christ's advent when He replaced it with new creation. After arguing this at length (Gl 1:11-4:31) Paul bursts onto

3 Both Betz (1979:272), and Longenecker (1990:238-9), correctly indicate that one should not regard ga.r as connecting Gl 5:13 with the preceding verses, but rather with the theme of freedom introduced in Galatians 5:1. 
stage announcing that freedom in Christ now fills centre-stage. In Galatians 5:2-12, knowing there were Judaisers encoring law to reappear to play some part in new creation, he admonishes them that only Christian freedom belongs on stage. Recalling the past was tantamount to rejecting the new player (G1 5:4). Soteriologically and ethically it was useless. It would reintroduce hopelessness (G1 5:5) and render the cross futile (Gl 5:11). Thus Gl 5:13 again focuses on freedom.

The second time around (Gl 5:13) is similar in mood and intention and equally indicative of freedom as soteriological and ethical sum of God's intention with the Christ event. It was not a mere by-product of the Christ event, but God's purpose. His use of $\kappa \alpha \lambda \in \hat{\imath} \nu$ echoes this purpose. In Galatians 1:6 he refers to God, the One by whose initiative they believed, as "Him who called you" ( $\tau$ ov̂ $\kappa \alpha \lambda \lambda^{\prime} \epsilon \alpha \nu \tau 0 \varsigma$ v $\mu \hat{\alpha} \varsigma$ ) (Morris, 1996, 163-4). This is reiterated in

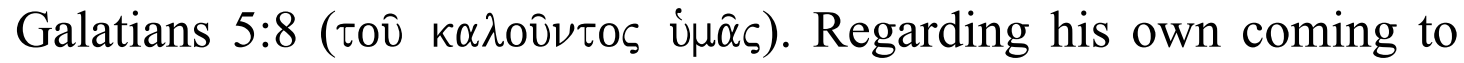
faith and receiving his calling to preach to the Gentiles (Gl 1:15), he

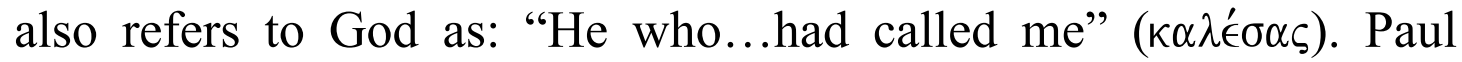
undoubtedly regards the believer's advent of faith as God's initiative and vocation for him (Coenen 1975:275-6; Schmidt 1965:489). Equally, when he refers to freedom as something to which the believer is called, without specifying when it happens, one assumes it is the very same thing viewed from another perspective. Freedom is not optional to faith. Not only is it part of the believer's coming to and living in faith, it is the sum of salvation. Paul emphasises freedom as goal for the Christian (Bruce 1982:240): an indicative that must be concretised as faith answers to God's call to salvation in Christ. Freedom is Gabe und Aufgabe.

"God did not take them out of their pre-Christian bondage, of whatever sort it was, simply to entangle them in another sort of bondage. It matters a great deal to Paul that Christians are freed people. He is not saying that a certain measure of liberty was grudgingly accorded believers. He is saying that freedom is of the essence of bein $\mathrm{g}$ Christian; it is the fundamental basis of all Christian living..." (Morris 1996:164).

However, for all their similarities, Galatians 5:1 and 13 also differ. Firstly, Paul's arguments up to Galatians 4:31 were heavily tinted with circumcision and law. Galatians 5:1-12 is transitional, summarising the foregoing and introducing Galatians 5:13-6:10. The 
latter is none other than an application of freedom from the flesh, since Paul had now elaborately dealt with freedom from the law. Bear in mind, Paul introduced the letter with the notion of deliverance from the present evil age (Gl 1:4) with its slavery to sin and flesh, and law and the elements of the world. When Paul returns to the believer's status of and call to freedom he is not addressing a new enemy from the left as opposed to law as a threat from the right. He merely returns to the root of man's problem, his being a slave to flesh. He leads the reader past the immediate danger of being reenslaved to law, to the more fundamental danger, inclusive of the immediate one, of being re-enslaved by flesh. Believers were no longer and could no longer be slaves to law. As an entity and way of thinking and doing law had become irrelevant. The problem was that sin and flesh had not stopped operations. Thus, Paul's focus turns to flesh, not as a new threat in the absence of law, but as the actual threat even in the time when law was applicable ${ }^{4}$ Turning to flesh, he turns to that which prompted Yahweh to introduce law in the first place. Interestingly, with the exception of two references to law (Gl $5: 14,23)$ the concepts Paul employs were used throughout the Hellenistic world. Obviously the meanings and conceptual frameworks were not identical, but the terminology provided his readers with a broader horizon than a strictly Jewish one. This is especially true of Paul's list of virtues. I am not arguing that they were strictly of Hellenistic origin; certainly not! What is undeniable, however, is that these terms were, unlike Torah, not strictly Jewish, so that a wider audience could identify with it. It seems reasonable, considering that Paul was trying to reframe the Galatians' lawdetermined symbolic universe, that at this point of exhortation he broke through the old mould and started forming a new way of thinking.

Secondly, Paul's exclamation on freedom (G1 5:1) was immediately followed by an exhortation to stand firm in that freedom and not to submit to slavery. Slavery was the negative

4 One is reminded of the remarks by Pretorius (1992:443): "[W]hereas the main antithesis developed in the first part of Galatians (Chs 1-4) is that between law and Spirit, the other big antithesis, in the second part of Galatians (Chs 5-6) is that between flesh and Spirit. Though the flesh controversy is already heralded in the first part (3:3) and the law controversy still echoes in the second part $(5: 14,18,23)$ '". 
characteristic of the old age under domination of $\sin$ and flesh. Christ had dealt with it. It was not to be revived. On the other hand, after reaffirming the believer's freedom as a vocation and purpose, Galatians 5:13 calls on them to be slaves to one another in love. He uses the very same metaphor to make two diametrically different points. In the first case he warns against slavery from the side of the present evil age that formerly deprived him of life and from which he had been freed. In the second case he turns away from the latter to that with a view to which they were freed, i.e. to love and serve one another. Paul also touched on this subject in Galatians 5:6. The one is about having no life at all, and the other about experiencing life in doing and receiving loving service.

"The freedom that Christians have been called to is new life in Christ: a life of selfless and other-directedness, which automatically places them at the disposal of others. A community of Christians, therefore, is ideally made up of persons 'enslaved' to each other, but even if some relationships are not fully reciprocal the attitude should be maintained" (Carter 1997:63).

It should be clear, Galatians 5:1-12, being transitional, is more focused on the believer's freedom from slavery, only touching on love as goal (G1 5:6). Galatians 5:13-24 is focused on the goal of freedom, employing the metaphor of flesh to define that goal and vocation clearer. Thus, in Galatians 5:13-24 Paul moves to ethically more positive terrain, defining how Christian ethics works in the paradigm of freedom (Jones 1987:102f). Significantly, at this crucial point, Paul does not warn the Galatians against "lawlessness", but against "opportunity for the flesh". He ignores law, probably hinting at its irrelevance. Not even sin is now defined by law! It all boils down to the flesh-Spirit opposition.

\subsection{Flesh has been crucified, remember!}

A few structural observations on Galatians 5:13-24 should be made (see diagrams below). The main theme is in Galatians 5:13a ("You were called to freedom, brothers!'), followed by the call in Galatians $5: 13 \mathrm{~b}$ (B) not to use freedom as an opportunity for the flesh. It is revisited in Galatians 5:24 (*B) stating that those belonging to Christ have crucified the flesh. As a chiasmus revolving around flesh, they emphasise that believers should not fear even the possibility of flesh leading to licentiousness, as if flesh were on a par with the Spirit. In 
their belonging to Christ, being crucified with Him, flesh had been crucified. He emphasises flesh's impotence. It was crucified "with its passions and desires" (Gl 5:24). He frames the ethical Spirit-flesh dualism and call to loving service with Christ's defeat of flesh. The believer is not dealing with equals.

Is Paul not being naive? Did he regard flesh as inoperative in Christians? Evidently not! In the centre of this chiasmus (Gl 5:17) he clearly states flesh and Spirit's opposition, speaking in a much personified way of flesh and Spirit desiring the opposite of each other and preventing believers from doing what they want. Clearly, flesh desires to frustrate the believer ethically. Despite the danger of succumbing to its allure, he follows by placing a positive frame around the flesh-Spirit opposition. He calls on believers in Galatians 5:16 (E1-2) to walk by the Spirit and not to gratify the flesh. $\Lambda \epsilon \gamma \omega$ $\delta \epsilon$ indicates the absolute importance of the following statement (Betz 1979:277). At the other end of the frame (G1 5:18 -*E1-2) he restates the notion, although differently. He replaces the desires of the flesh (E2) with being under law (*E2). Clearly, he underlines the flesh-law alignment as allies in opposition to the Spirit. E1 and *E1 are more important. Firstly, he calls on them to "walk by the Spirit" ( $\pi \nu \in \hat{U} \mu \alpha \tau \iota \pi \epsilon \rho\llcorner\pi \alpha \tau \epsilon i \tau \epsilon$ ), an imperative defining the Christian way of life (Betz 1979:277). Galatians 5:18 (*E1-2), although on the same topic, has a slight nuance, reading: "But if you are led by the Spirit you are not under the law". The use of the connectors $\epsilon i \quad \delta \epsilon$. to introduce the conditional clause, is significant. Moule (1953:150) states that if the protasis is a present condition in the indicative mood, as in this case, it refers to a matter of certainty, an existing condition. Paul is not saying if they were to be led by the Spirit (subjunctive mood) they would not be under law, but actually, because they are led by the Spirit, they are not under law. Thus, in E1 he calls on them to live according to the status they already have (*E1). The sum effect of this frame is to state that, although flesh and Spirit are in conflict, the believer's secret to withstanding flesh is his being led by the Spirit.

Immediately around this frame that holds the secret to Christian living, Paul places another, i.e. Galatians 5:15 (D) and Galatians 5: 19-21 $\left({ }^{*} \mathrm{D}_{1-4}\right)$. He parallels the Galatians' in-fighting (Gl 5:15) with works of flesh (G1 5:19-21), and in absolute contrast to a Spirit led life. Immediately around this, in opposition to a life without love and according to flesh, he emphasises the sought after 
life of love. G1 5:13c-14 $\left(\mathrm{C}_{1-2}\right)$ is explicit about this. Parallel to this is the fruit of the Spirit in Gl 5:22-23 $\left({ }^{*} \mathrm{C}_{1-3}\right)$ with love as principal element of the fruit of the Spirit.

13a. You were called to freedom

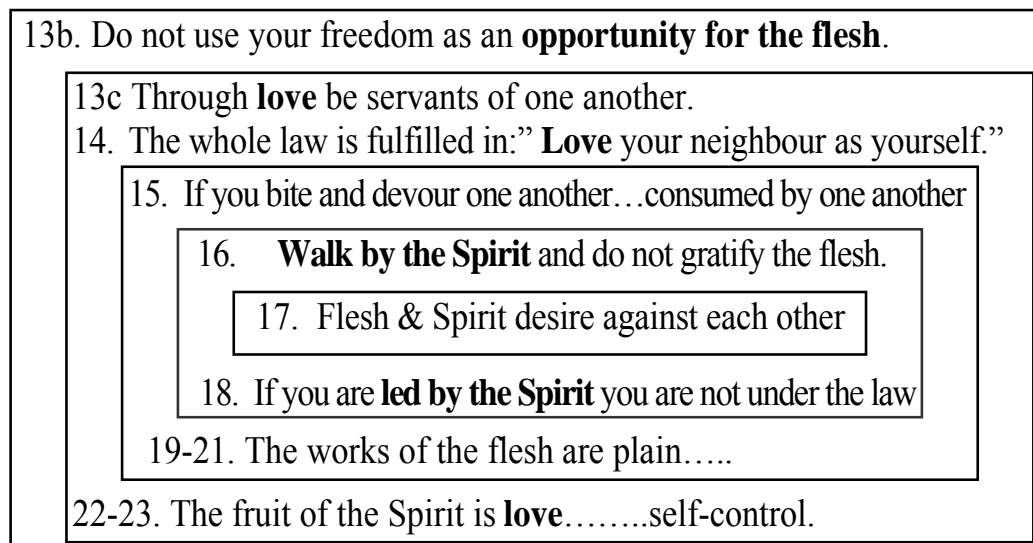

24. Those who belong to Christ Jesus have crucified the flesh...

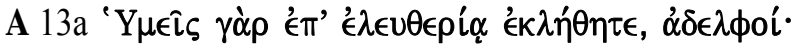

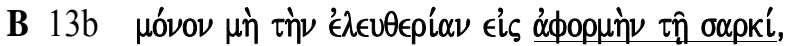

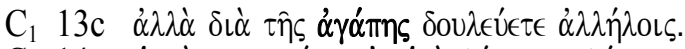

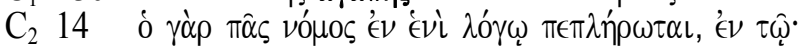

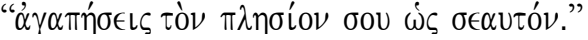

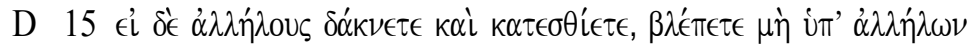
$\dot{\alpha} \nu \alpha \lambda \omega \theta \hat{\eta} \tau \epsilon$.

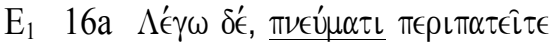

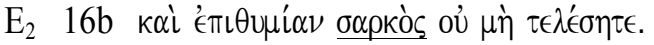

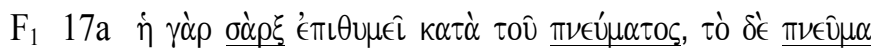

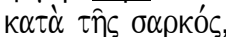

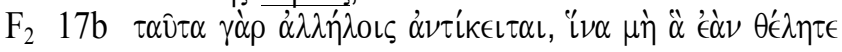

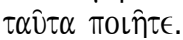

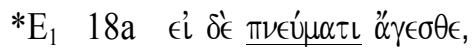

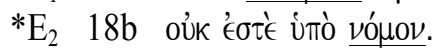

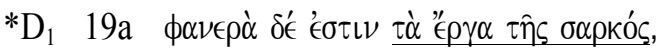

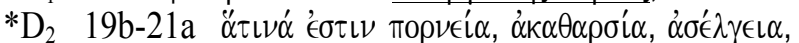

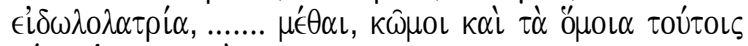

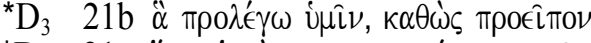

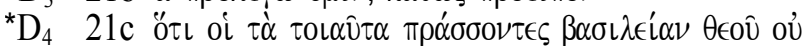

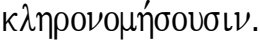

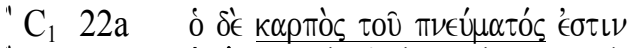

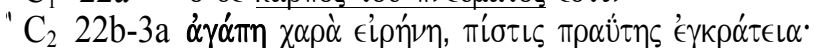

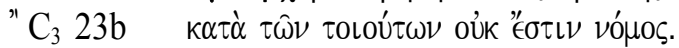

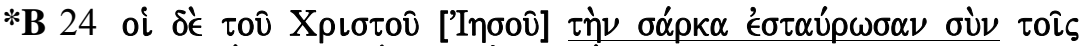

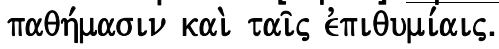

In sum, Paul accepts that flesh and Spirit are in conflict. Believers were not to live in a fool's paradise. They were free from the present evil age, but the latter had not yet been annihilated. It was a matter 
of waiting in hope of righteousness (G1 5:5). The time of reaping (G1 6:7-9) had not yet come. However, succumbing to flesh was totally unnecessary and unwarranted. Although flesh desires to frustrate the believer, it no longer has the dominant role it used to have in the believer's pre-Christian life. In no way is it on a par with the Spirit. The believer is not helplessly exposed to flesh. Now that he belongs to Christ, not only has flesh been crucified (Gl 5:24), but the Spirit has become the major Persona and guiding influence in his life. The new life in Christ is portrayed as beginning with the Spirit who worked miraculously in their lives (Gl 3:3-5). The Spirit of the Son through whom they call: " $\alpha \beta \beta \alpha$ o $\pi \alpha \tau \eta$ ' ${ }^{\prime}$ ", lives in them (G1 4:6). Through Him they have new life and live it by his guidance (G1 5:25).

Galatians 5:13-24 does not reflect an ethical battle in the believer, with two equals trying to win over a helpless person. Rather, it reflects the responsibility of the believer not to do what flesh desires, because he has no need to do so. One must also guard against thinking of the battle between Spirit and flesh as one "which inevitably results in flesh frustrating the Spirit-inspired wishes of the believer" (Barclay 1988:113). Neither are they in stalemate. I agree with Barclay that Galatians 5:17, referring to the Spirit-flesh conflict

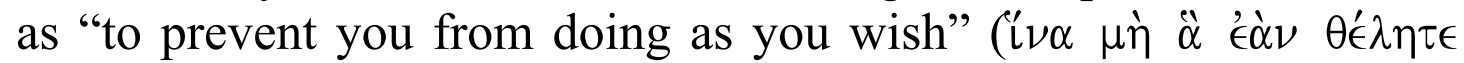
$\tau \alpha \hat{v} \tau \alpha \operatorname{\pi o} \hat{\eta} \tau \epsilon)$, does not mean that the believer is a pawn in the hands of two opposing and imposing entities. Rather, it stresses the believer's responsibility to associate freely with the Spirit and not to be dominated by flesh (Barclay 1988:114-5,215). The believer's position is profoundly different from that in the old aeon, when he was naturally inclined to domination by flesh. Now, being a new creation, flesh having been crucified, he enjoys the indwelling of the Spirit orientating him to God's will (Gl 1:4; 4:6). He has no reason to succumb to flesh's lures.

\section{THE SECRET OF LIVING FREE: WALK BY THE SPIRIT!}

Christian ethics operates under the guidance of the Spirit. The Christian is not oriented to law, but to Christ and his cross. How should the accompanying ethic be shaped and practised? In as much as the foundation, norm and purpose of Christian ethics can be described as loving service of the kind that befell believers in Christ, and which does not come naturally, the Spirit of Christ is the one who motivates and enables the believer to perform the deeds of love 
and service to which we are called. Christian ethics is thus christologically founded and pneumatologically implemented

"It is this overwhelming presence of Christ, the crucified and resurrected Lord, his Spirit, 'the fruit of the Spirit,' which prevents the intentions of the flesh from accomplishing the "works of the flesh' (cf 5:16, 19-21a)" (Betz 1979:289).

\subsection{Walk according to the Spirit}

Paul describes the relation between the Spirit and the believer with three similar sounding expressions, i.e. $\pi \nu \in \cup \dot{\mu} \mu \alpha \tau \iota \quad \pi \in \rho \iota \pi \alpha \tau \in \hat{\imath} \tau \epsilon$ ("walk

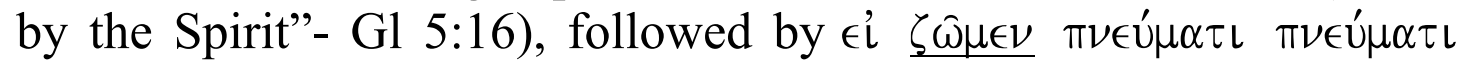
$\kappa \alpha i$ $\sigma \tau o\llcorner\chi \hat{\omega} \mu \in \nu$ ("If we live by the Spirit, let us also keep in step with the Spirit" - Gl 5:25). I disagree with Longenecker (1990:244) that

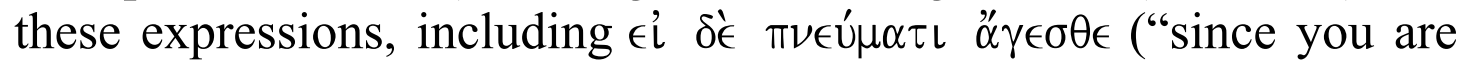
led by the Spirit" - Gl 5:18) are synonymous. The mere use of two

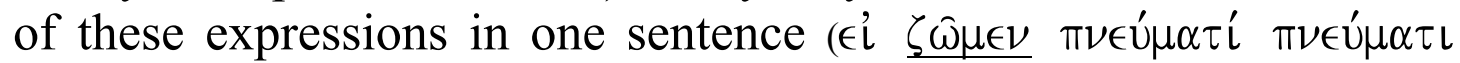

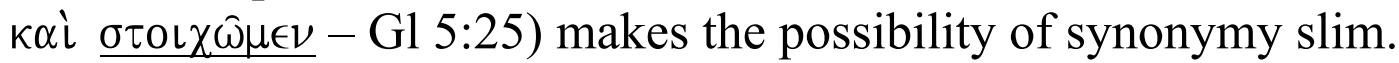

\subsubsection{E’ $\zeta \hat{\omega} \mu \in \nu \pi \nu \in \dot{u} \mu \alpha \tau \iota$}

This is a soteriological expression reminiscent of Galatians 3:3-5 where Paul refers to the Galatians' coming to faith as an act of the Spirit. Their new life began with the Spirit. Through the Spirit of the Son the Galatians became sons of God calling: "Abba! Father!" (G1 $4: 5-7)^{5}$. Although Paul had not, at that stage, used the term "new creation" (Gl 6:15), he had implied it with his reference to the receiving of the promise of the Spirit through faith in Christ (Gl 3:14). The OT promised new life in which God's Spirit would be central. Paul refers to this pneumatological life as new creation.

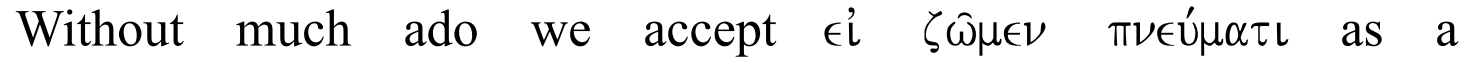
pneumatological-soteriological reference to new life through the Christ event as existentially realised in the believer through the Spirit (Hansen 1997:224) ${ }^{6}$. In other words, it emphasises the new

$5 \quad$ Schrenk and Quell (1967:1006), stress that Paul's use of vabba is more than a liturgical formula. It refers to adoption as son of God. It is about "joyous assurance" in contrast to the slave. The vabba cry is the opposite of nomism. Through his Spirit, Christ has created a Father-son relationship.

6 Longenecker (1994:189), stresses the close association between Christ and the Spirit, speaking of a "change in soteriological order from, (1) the 
status of the believer. It summarises the soteriological indicative of Christian life (Betz 1979:293). Using $\in \dot{i}$ ("if") followed by the indicative $\zeta \hat{\omega} \mu \epsilon \nu$, Paul again equates life in the Spirit as inseparable from being a Christian?

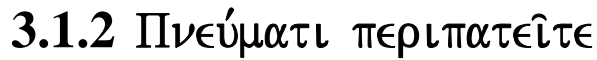

This expression intends a different nuance. For a start, it is an imperative emphasising faith as a 'way of life' (Betz 1979:277). It is not only about an indicative ascribing status (being introduced to a new life by the Spirit), but equally about a way of life in which one is governed by Him in enacting one's faith (Ebel 1978:944). Thus one could equate $\pi \nu \in \dot{u} \mu \alpha \tau \iota \pi \epsilon \rho\llcorner\pi \alpha \tau \in \hat{\imath} \tau \in$ with its chiastic double $\pi \nu \in \dot{\mu} \mu \alpha \tau \iota$ " $\gamma \in \sigma \theta \epsilon$ ("to be led by the Spirit" - Gl 5:18) (Bruce 1982:245). It is about allowing the Spirit to determine one's conduct (Bruce 1982:243). "Walk" is atypical to Hellenism, but typically Jewish (Dunn 1993:295, citing Ex. 18:20; Dt. 13:4-5; Ps. 86:11; Is. 33:15; and 1QS 3:18-4:26. Also Bertram \& Seesemann 1967:941-3; Ebel 1978:943-4). The Hebrew root הלד from which halakah ("legal ruling") is derived, is the operative OT word (Helfmeyer 1977:41533; Lull 1980:121-3). "To walk according to the statutes of Law" (Ex. 16:4; Lv. 18:4; Ezk. 5:6-7) was a Jewish reference to conduct befitting God's people. Paul alludes to law by using an OT reference for proper conduct, and contrasts it with walking in the Spirit (Witherington 1998:393). This is significant, because his main aim, judging from the apodosis, was to explain that the Spirit was the One through whom they had to deal with flesh. Speaking in the old law jargon he probably restated law's inability to deal with flesh. This is enhanced by his categorical statement (Gl 5:18) that the Spirit makes law defunct. In this case he uses $\pi \nu \epsilon \dot{u} \mu \alpha \tau \iota \stackrel{\alpha}{\gamma} \gamma \in \sigma \theta \epsilon$, the parallel of $\pi \nu \in \dot{u} \mu \alpha \tau \iota \quad \pi \epsilon \rho \iota \pi \alpha \tau \in \hat{\imath} \tau \epsilon$.

"[T]hose who had been given the Spirit thus also knew the eschatological experience looked for in Jer. xxxi.33-4 - an immediate knowledge of God, an enabling to know what God's will was in particular instances. This is the basis of a charismatic ethic, depending more on inward

reception of the Spirit to being a child of God as in 3:2-5, 14b and 26, to (2) being a child of God as the basis for receiving the Spirit, as here in 4:6".

7 Moule (1953:150); Morris (1996:176). Witherington (1998:412), correctly suggests "since" instead of "if". 
apprehension of what is the appropriate conduct than on rule book or tradition" (Dunn 1993:296).

The metaphor denotes progress towards a Spirit-denoted destination. Morris stresses that the present imperative has the force of "keep walking in the Spirit". Being in Christ, having begun in the Spirit, he accepts they are walking in the Spirit (Morris 1996:168; Lull 1980:154-61).

"Paul constantly speaks of what the Spirit does, so that believers are 'led' by the Spirit $(5: 18)$, he refers to 'the fruit' of the Spirit $(5: 22)$, and of 'reaping life eternal' from 'sowing to the Spirit' (6:8). The apostle is telling his readers what the Spirit does in them, not what they themselves can accomplish if only they try hard enough" (Morris 1996:168).

Thus we can reiterate that Paul does not change from a soteriological to an ethical course. He merely takes the soteriological course to its ethical consequence. In as much as the Spirit is the One by whom the believer lives soteriologically speaking, $\mathrm{He}$ is equally the One through whom the believer expresses this life ethically (Schreiner, 2001:263).

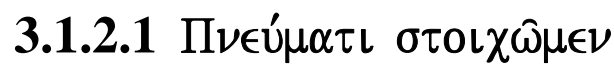

Although this phrase is essentially similar to $\pi \nu \in \cup \dot{\mu} \mu \tau \iota \quad \pi \epsilon \rho \iota \pi \alpha \tau \in \hat{\imath} \tau \epsilon, \mathrm{I}$ believe Paul intended a nuance (Betz 1979:293). Once again he emphasises faith's indicative and imperative, but, significantly, uses them in one sentence. Thus, the indicative to live by the Spirit is inseparable from the imperative to obey the Spirit. Christian life is not an idle waiting on the Spirit to provide the fruit, but an active struggle in which the fruit which the Spirit provides are made manifest.

Paul's earlier reference to the elements of the world ( $\sigma \tau \circ \chi \chi \in \hat{i} \alpha$

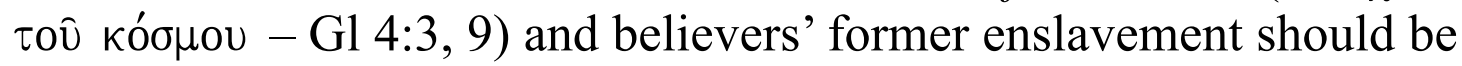
remembered They were dictated to and lived according to these elements of the present evil age. Paul probably alludes to these elements - including law - to reaffirm the radical switch from flesh to Spirit. They were not to think in terms of the old paradigm, but to

$8 \quad$ Fee (1994:204): "Having begun by the Spirit, one comes to completion by the Spirit". 
listen to and follow the Spirit. The term is reintroduced in Galatians 6:16. It is a military term meaning "to be drawn up in a line" in order to follow a leader (Betz 1979:294). It was used in Hellenism with regard to following philosophers and their teachings (Delling 1971:667). It could be that just as he used Jewish ethical terminology ("walking by the Spirit") he now uses Hellenisic terminology to drive the point home with a largely Hellenistic audience. Be that as it may, if Paul used the verb in a military sense, it would mean that the Galatians were to fall in line and follow the Spirit's ethical leadership. This fits the context extremely well, because Paul places profound emphasis on the faith community corporately and harmoniously acting in accordance with the Spirit (G1 5:26-6:10).

"The overtones then are that if the Galatians want to place themselves under a sort of martial law, all they really need to do is stay in step with the Spirit and they will receive all the guidance and discipline they need" (Witherington 1998:413).

The ethic of freedom does not resemble licentiousness or anarchy. It involves a well-ordered life in the absence of dictates, including natural ethics (elements of the world), but according to the loving inner guidance of the Spirit bringing about new creation in Christ's advent.

"The Spirit which effects this disregard of self is in no sense legal, still less legalistic; yet in its effect it is entirely moral" (Barrett 1985:77).

\subsection{The fruit of the Spirit}

How does a pneumatological ethic function? How does the Spirit impact on the individual believer and community? How does the Christian ethic differ from Judaism and pagan religions and philosophies? Is the difference in the content or in the way it functions?

\subsubsection{Living the life He makes possible}

The Christian ethic differs as radically from any other ethic in as much as Christian faith and soteriology differ from other religions. Christian soteriology is about God taking the initiative and providing believers with salvation through grace alone. He actualises this salvation in believers by his Spirit who endows them with faith in 
Christ. It is no different in Christian ethics according to which Christ equally lives in the crucified man through the gracious guidance of the Spirit. The effortless way in which Paul moves from his theological to his ethical arguments is witness to this. Reading Galatians 4:21-31, one is still aware of the heavy theological element in Paul's argument. One senses that whilst Galatians 5:1 summarises the theological section, it also turns the line of argument to ethics. This is actually true of the entire Galatians 5:1-12. Reaching Galatians 5:13, one almost suddenly realises that one is in the ethical section boots and all after already having entered it at Galatians 5:1. He does not give the impression that at a given point theology ends and ethics takes over, or that ethics is a totally different ball game. Paul's soteriology of freedom through Christ determines his ethic of living that freedom under the Spirit of the Son's guidance and inspiration.

\subsubsection{The fruit of the Spirit: inevitable result of faith in Christ}

Paul says it all with the term fruit. It was not about ethically encoded guidance from outside the believer's being. Gone were the days that a law would command believing sinners without providing them with the ability to do as it commanded and heaping guilt upon guilt. It was now about an ethic that was equally as much a solution to man's ethical plight, as it was to his soteriological need for new life. It was about living the new life according to God's promise in which the Spirit would deal with and guide the believer from his inner being. It would be equally incomparable to the ethics of pagan religions and philosophies. It would not be about human endeavour to improve life by arduously striving to live detached from the mundane, and reaching to obtain a certain level of virtuosity, termed freedom. It was about the Christian being endowed with a new character, which determines his new ethic (Dockery 1993:317; Hansen 1999:210-1).

It is evident, Paul wanted to create a clear contrast between works of the flesh (Gl 5:19) and fruit of the Spirit (G1 5:22). It is likely that Paul, having moved on from his arguments against law, now focusing on the real problem, namely flesh, actually implied the works of the law and grouped them together with the works of the flesh. There are a few reasons for this assumption. He used works of law abundantly in his argumentative section where life according to law featured in the frontline of attack against his gospel. He now moves on to deal with morality's root problem, i.e. flesh, and refers 
to all deeds done according to flesh as works of the flesh. In Galatians 2:16 he thrice refers to works of law, stating that justification could only be through faith in Christ and not "by works

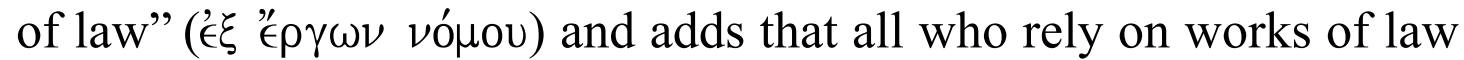
are under a curse (Gl 3:10). Does he not say the same of works of flesh when he states that those who do such things will not inherit the kingdom of God (G1 5:21)? Not being part of God's kingdom, especially in apocalyptic sense, equals separation from God and thus not being in the realm of salvation. Seeing Paul's words against the background of Jesus' parables on the kingdom (e.g., Mt 24-25; Mk 13; Lk 12:35-48; 13:6-9, 22-30; 14:15-24), this implies being under God's judgement (Klappert 1976:382-9).

There is the added possibility that Galatians 5:19-13 revisits Galatians 5:14-15. In Galatians 5:14 Paul states that the whole law is fulfilled by love. When we read of the fruit of the Spirit, starting with love, ending with self-control and mentioning all the other elements as ways in which the first element is concretised, it rings a bell reminding us of Galatians 5:14. Equally, a few obvious works of flesh come to mind when one reads Paul's hyperbole concerning the Galatians' devouring of one another (Gl 5:14). The implication is that their in-fighting about works of law led them to doing some of the works of the flesh, e.g. enmity, strife, jealousy, anger, selfishness and envy.

In Galatians 3:2, 5 he ascribes the receiving of the Spirit to faith and not to works of law. Thus, speaking of fruit of the Spirit (G1 5:22) in opposition to works of flesh he refers to something equally as unattainable through law as through flesh. It would be stretching the argument too far to assert that Paul equates works of flesh and works of law. However, it seems that Paul, at least by way of analogy, groups these two together and that the works of the law should be understood as included in his denouncement of the works of the flesh. This is even more obvious, considering how Paul regards law as one of the elements of the world (Gl 4:3).

Ultimately both are driven by human effort. Successes occur in the broader spectrum of behaviour, but in the long run human effort cannot deal with flesh and succumbs to its lures. In contrast to these works the Spirit produces a fruit that is otherwise humanly 
impossible9. Being crucified with Christ and Christ now living in him (G1 2:20); being dead to the law (Gl 3:19); being crucified to the world and the world to him (Gl 6:14); having the Spirit doing miracles (G1 3:5) living in him and through whom he has an intimate relationship with God, calling " $\mathbf{k} \beta \beta \alpha$ o $\pi \alpha \tau \eta \rho$ " (Gl 4:6); and, in summary, being a new creation (Gl 6:15), the believer no longer needs to experience ethics as a never ending struggle moreover leading to defeat, guilt and curse. There is a profound spontaneity in the pneumatological ethic - something effortless!

"Paul wishes to stress that in those who have been received into the body of Christ, in whom the Spirit of Christ is active and who have a share in the gifts of this living fellowship, the outworking - the fruit - appears naturally, because it is not something manufactured" (Hensel 1975:723).

"True Christian freedom, therefore, is the experience of this subjective restoration of the image of God through union with Christ so that the objective revelation of God's holiness and righteousness in the person of Christ can be expressed in ethical conduct" (Hansen 1999:212$3)$.

\subsubsection{The fruit of the Spirit as a gift of grace excluding achievement}

The point having been made that the Spirit produces God-pleasing fruit in the believer, and that the latter's good works are not an achievement of his own, the question arises as to the nature of this divine gift. One must steer clear of the notion that the mentioned virtues are given to the believer as a possession upon which he can call randomly and manifest automatically (Betz 1979:286-7). The listed virtues are not given as "finished products," so to say. The Spirit leads them and makes them aware of God's will, so that, if they are obedient, these virtues manifest in their lives. It happens neither automatically nor at gunpoint. Referring to Galatians 5:22 and Roman 1:16 Deidun puts it well.

"What the imperative demands of the Christian is, in essence, only what the Gospel itself demanded of him at

9 Longenecker (1990:259); Matera (1996:172). Esler (1998:226-7), stresses that the believer now had access to more than law could provide, i.e. love, but via a different route, i.e. the Spirit. 
the time of his initial believing: docile obedience. For the

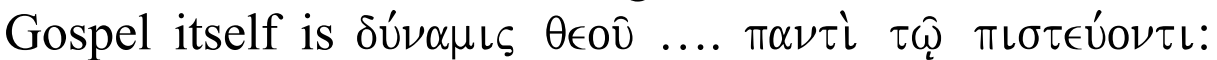
the present participle indicates the 'yes' by which the Christian, at the time of his conversion and throughout

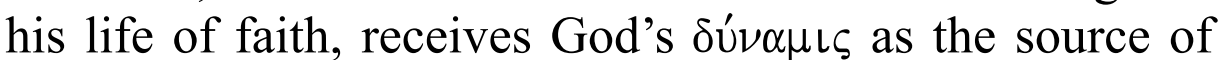
his own dynamism in faith and love. A man's salvation...is conditional upon his willingness to be saved.... Even a gift that is already bestowed is conditioned by the recipient's willingness to retain it" (1981:82).

The believer's active involvement is never eliminated. It is about the Spirit enabling believers to produce these qualities and deeds for which they do not have a natural inclination. Their responsibility was not to strive to fulfil a given list of virtues, but to live and walk according to the Spirit and in the process to experience how $\mathrm{He}$ produces such and other virtuous behaviour. The Christian's life is about surrendering to God's work in Christ which He does through the Spirit ${ }^{10}$.

\subsubsection{What law could not do, it can now only applaud}

While describing Christian ethics as one in which the Spirit provides the guidance and ability to live in the faithfulness of Christ; and focussing attention on the Spirit as the only antidote to flesh's desires, Paul once again mentions the Christian's not being under law (Gl 5:18), as well as law's obsoleteness (Gl 5:23). In fact, he frames the lists of vices and virtues with these remarks. Law could not deal with flesh. Having been provided with the Spirit the Christian is now able to deal with flesh. Law having failed in its function to deal with flesh in the old dispensation, no longer had a role to play in the Christian's ethical decisions. The Spirit was now doing what law could not do (Westerholm 1997:162-4; Bruce 1984:63). Law had thus become obsolete. Ironically, the only positive ability law possessed was to underline man's guilt and cursedness (G1 3:5). It could not produce faith or help man to live according to the promise. In fact, because it was based on man's

10 Bornkamm (1966:48), stresses the bond between indicative and imperative: "...die Dringlichkeit des Imperativs ist erst recht dadurch begründet, dass die Entscheidung gefallen ist: wir sind von der Sünde befreit... Was die Glaubenden zu tun haben, ist sehr schlicht und einfach das parista, nein, das Sich selbst.....Gott überlassen". 
endeavours, Paul referred to it as works of law, aligning it with works of flesh. In fact, he even adds that there is no law against such (G1 5:23). Law in its entirety had to applaud the Spirit's success, itself having become superfluous, irrelevant and obsolete.

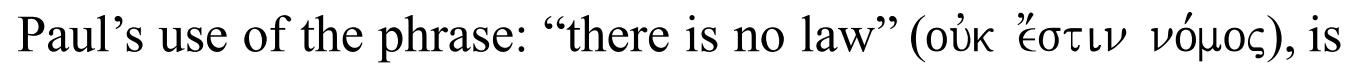
notable. It seems Paul might have had all ethical systems in view. The qualities the Spirit produces are above reproach from any ethical source and praiseworthy in any company. By distinguishing these qualities from law, Paul implies that the moral qualities expected of Christians are not a new law (Betz 1979:288). Frankly, they could not be regulated by any kind of law without being compromised. How does one enforce love? Does it not cease to be love if it is forced? Was this not the problem in the old aeon? Flesh cannot produce love. Law cannot force love. Love is a quality born from the heart by the movement of the Spirit.

"The (somewhat unexpected) mention of the Law in v. $23 \mathrm{~b}$ - in itself an ironical statement of the obvious - is intended to remind the Galatians that agapê (in all its multiform manifestations) belongs to a sphere in which the Law is simply irrelevant - and not just in the sense that the Law contains no statutory prohibition of agapê, but in the deeper sense that the Christian now lives no longer on the basis of human molel $v$ but in the power of the Spirit. Not man, but God himself, is the source of the Christian's activity" (Deidun 1981:118).

From Paul's utterances in Galatians one can safely deduce that law has no function in Christianity, neither soteriologically, nor ethically. Although Paul, as former Jew and advocate for the fact that Christianity cannot ignore its Jewish roots (Rm 11), was positive about law's divine and necessary function in the old aeon, he rejected the necessity of law as an external requirement for Christian guidance. Law had been replaced by the activity of the indwelling Spirit (Gl 5:18). The moral demand on the believer was now based on the authority of the crucified and risen Christ (G1 2:20). Paul's own references to Mosaic laws in other correspondence do not indicate that he regarded Mosaic law as necessary ethical enlightenment. These demands were obviously so much in accordance with Yahweh's demand to love, that it was required of believers to abide by them as far back even as Moses, as a matter of spiritual commonsense. 


\section{FREEDOM'S NORM AND PURPOSE: LOVING SERVICE!}

\subsection{Less is more. No longer doing law, but fulfilling it!}

In Galatians 5:14 Paul clearly reminds the readers of the ethical maxim well-known in Judaism (Lv 19:18) and reiterated by Christ (Mt 19:19; 22:39; Mk 12:31) as the primary maxim according to which one should relate to others: "Love your neighbour as youself"'.

This was in stark contrast to the devouring character of their polemic (Gl 5:15) (Betz 1979:277). By referring to this misconduct immediately after the aforementioned maxim he probably meant to illustrate law's impotence. Despite the implied pursuit of lawobservance via circumcision, diet and calendar, the Galatians were probably at odds with one another, illustrating how inadequate law was in fulfilling its own goal of enhancing mutual love. He hints at this possibility again in Galatians 5:26. If one were to accuse Paul's stance on Christian freedom from law as an opportunity for the flesh and as morally bankrupt, Paul could reciprocate that Judaism had proven the possibility of moral bankruptcy in the midst of, and sometimes even via, law. They aimed to do the law, but grievously failed to fulfil it in love. However, steering clear of such a direct accusation and the possibility of dignifying such a position, Paul resorts to positive argumentative territory. He sets love as the goal of Christian morality. What law could not attain because of its inability to deal with flesh, believers, without the stipulations of law, would now pursue by living according to the guidance of the Spirit (G1 5:16-18, 22f).

\subsection{An ethic of loving service to one another}

Paul makes four statements on love. Firstly, the life he lives in the flesh is lived "by faith in the Son of God, who loved me and gave

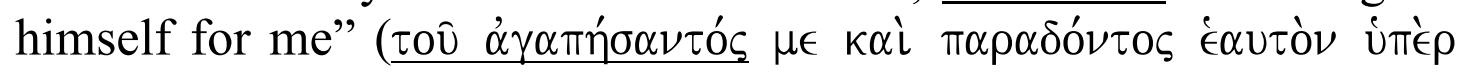
'́nov̂ - G1 2:20). It refers to the basis of Christian faith, salvation and ethics. Paul states that at the heart of Christian faith lies the divine initiative, drenched in the love of the Son of God who gave Himself

11 According to Deidun (1981:143), the demand for neighbourly love does not ignore the fundamental demand to love God (Dt 6:5). They are at different levels. Love for God is fundamental and implied in faith. Neighbourly love is wholly impossible if the subject is not authentically surrendered to God. 
unto death to deliver sinners. This was not only the ultimate token of love and self-sacrificing service, but also the basis and motive of Paul's and all Christians' love and service. Faith was founded on and lived in the faithfulness of Christ (Hays 1983:157-76).

Secondly, Paul is clear that the main issue of faith in Christ is far removed from circumcision. It is much rather about "faith

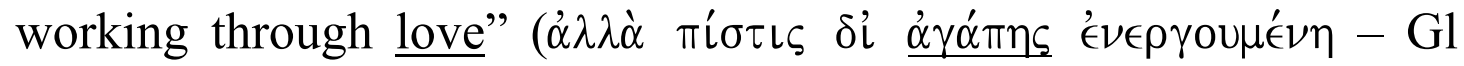
5:6). By juxtaposing circumcision with love he enhances the importance for Christians to love. While circumcision, the rest of law implied, was the most prominent mark of the true Jew, believers in Christ would essentially be characterised by faith translating into love.

"The two concepts come together because they are the two sides of the same orientation of a man. Faith denotes the attitude of openness or simple trust on the basis of which alone he can relate truly to God. Love denotes the generous self-giving which follows from it. Faith is a disposition of the whole person, love the moral impulse to which it gives rise; for to respond to God's love in simple trust must impel a man to be open to his neighbours' needs. Open self-giving must characterize a man in both dimensions - towards God and towards others" (Houlden 1992:29).

Thirdly, Galatians 5:13 calls on believers to put their freedom to

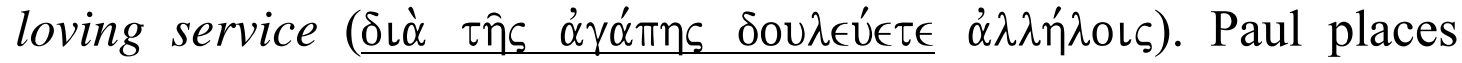
love and service in the context of Christian freedom as a vocation. The Christian is not set free as a goal in itself. He is set free from the enslaving bonds that made it nigh impossible to look beyond the self and to be other than self-serving. He now, after being freed, has the vocation to rise above flesh, serving in love (Guthrie 1981:696).

"Reading Gal 5:14 in its own letter, then, we are reminded in two regards of Paul's ubiquitous concern to differentiate anthropological possibility from christological power. First, we sense that for Paul the difference between anthropological possibility and christological power is nowhere more evident than in the daily life of the church (cf. Gal 5:22-24). Second, we see that in the church's life, that difference emerges precisely in relation to the question of the pertinence of the law. In Gal 5:14, 
that is to say, the guiding imperative of the law, Lev 19:18, is not the result of an insightful deed of Paul.... On the contrary, that guiding imperative is the result of the powerful deed of Christ, his act of loosing God's law from the law of Sinai, thereby addressing it to the church. The law taken in hand by Christ (Gal 6:2) is the law that Christ has restored to its original identity and power (Gal 5:14)" (Martyn 1996:60).

Christ removed the link between morality and law, grounding it in his love demonstrated on the cross. Christian morality takes its cue, not from law, but from Christ's love and faithfulness ${ }^{12}$.

Fourthly, in Galatians 5:22 Paul introduces the fruit of the Spirit and places love ( $\alpha \gamma \alpha \dot{\alpha} \pi \eta)$ at the prominent top position heading the list of Christian "virtues"13. At this stage it should be added that the also important last position is assigned to self-control

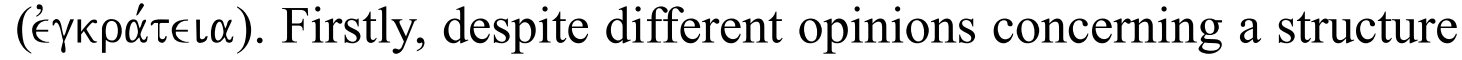
of some kind in Paul's list of virtues, there is extensive agreement that the first, i.e. love, is the all controlling quality from which the others flow and from which they take their cue (Dunn 1993:309). This once again illustrates love as the overriding Christian orientation from which the others are born and through which they are carried. It is this orientation to love that bears with others and shares their burdens, giving them direction and a specifically Christian content. Secondly, the element of service is introduced by $\epsilon \gamma \kappa \rho \alpha ́ \tau \epsilon \iota \alpha$. Of course, Paul's view on self-control is far removed from that of Hellenism. Broadly speaking, Hellenists took it to refer to man's ability to discipline himself, gaining control over his bodily and emotional being, so that he would not be dictated to by them, or even merely pleasure them. His main focus was mental and intellectual control of his life (Bredenkamp 2001:48). Obviously this led to a dispassionate disposition and disconnectedness from society

12 Marxsen (1993:217), refers to Christian love as lived Christology.

13 I would prefer the word "quality", although it needs qualification. A virtue gives the impression of something objective to be achieved. With quality I intend it as an expression of the gift of love worked in the believer by the Spirit; thus, quality as an expression of love. This is also why I agree with most scholars that the use of the singular for fruit points to this notion of the fruit of the Spirit being love expressed in different ways according to contextual need. All these ways must manifest in the Christian's life. 


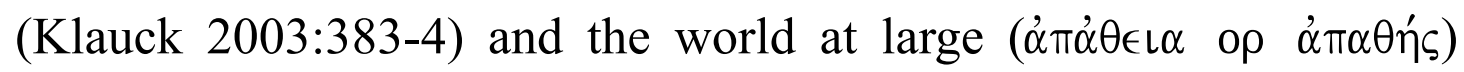
(Liddel \& Scott 1975:86; Gärtner 1978:719). In fact, it led to those successful in practising ' $\} \gamma \kappa \rho \alpha ́ \tau \in \iota \alpha$ regarding themselves and being regarded by others as a notch above the ordinary citizen (Bredenkamp 2001:49). Paul, on the other hand, has a more relational understanding of ' $\epsilon$ $\gamma \rho \alpha \dot{\alpha} \tau \in\llcorner\alpha$. It is not about mere control over one's emotions and desires. It should be seen more in the light of love and freedom, hinting towards being willing, through love, to hold back on one's freedom in order not to impose on the freedom of others (Bredenkamp 2001:195-8).

"It simply tells us that for the sake of the goal toward which he strives, the commission he has been given, and the task he must fulfil, he refrains from all the things which might offend or hamper" (Grundmann 1964:342).

Once again, Christian freedom is not the freedom to do whatever one wishes, even if it were not necessarily licentious. It is about being free to love and serve according to God's will. Paul regarded Christ's love and faithfulness as foundational for ethics. It is the driving force behind his ethic, as well as its norm and purpose.

\section{CONCLUSION}

Paul does not distinguish between soteriological and ethical freedom. "For freedom Christ set us free" (Gl 5:1), refers to Christ's entire work of salvation. Freedom is an encompassing term indicating the believer's new status and divine vocation since the demise of the present evil age of enslavement. The believer not only possesses the status of being free, but must practise his freedom to the full.

Paul's arguments against a role for law in Christianity apply not only to soteriology (legalism), but equally to ethics (nomism). In as much as the believer is free from flesh and sin through the cross of Christ and the quickening of faith by the Spirit, his ethical life is also characterised by the faithfulness of Christ and the quickening of the Spirit. The Spirit does not orientate the believer to a form of law according to which he is to live, but to Christ whose faithfulness sets him in the new aeon which is free of flesh's dominance, and provides him with the example of faithfulness to God's will. The Spirit guides the believer and enables him to do God's will and serve his neighbour in love. 
Christian ethics is not about striking a balance between freedom and some form of law observance. It is about producing the fruit of the Spirit without the help of law. In fact, law cannot be of any help. The christological-pneumatological ethic of freedom is essentially anomistic, but not libertinistic. It seeks to live faithful to Christ and his Spirit, and so to glorify God whose will Christ set out to fulfil (Gl 1:4). The Christian may not fear his freedom. It was given to him by his God and Father, and dearly paid for by the Son. He must honour God by trusting the Spirit to faithfully guide him in his celebration of this freedom.

\section{Consulted Literature}

Barclay, J M G 1988. Obeying the Truth: A Study of Paul's Ethics in Galatians. Edinburgh: T \& T Clark.

Barrett, C K 1985. Freedom and Obligation. Philadelphia, Westminster.

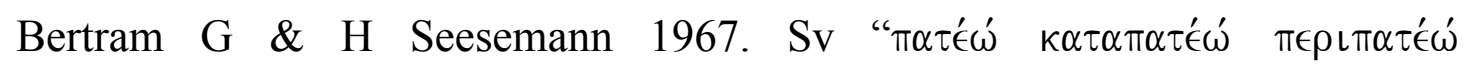

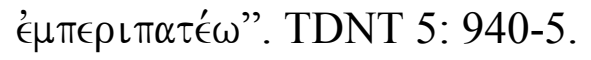

Betz, H D 1979. Galatians. A Commentary on Paul's Letter to the Churches in Galatia. Philadelphia: Fortress.

Bornkamm, G 1966. Das Ende des Gesetzes. Paulusstudien. Gesammlte Aufsätze 1. München: Chr. Kaiser

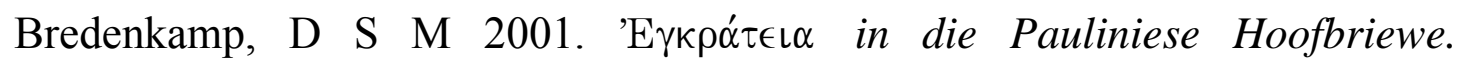
Unpublished Dissertation: University of Pretoria.

Bruce, F F 1982. The Epistle of Paul to the Galatians. Grand Rapids: Eerdmans.

-, 1984. "Called to Freedom': A Study in Galatians," in W C Weinrich (ed), The New Testament Age. Essays in honour of Bo Reicke. Macon: Mercer University, 61-71.

Carson, D A, P T O'Brien \& M A Seifrid (eds) 2001. Justification and Variegated Nomism, 1: The Complexities of Second Temple Judaism. Tübingen: J C B Mohr - Paul Siebeck.

Carter, P 1997. The Servant Ethic in the New Testament. New York: Peter Lang.

Coenen, L 1975. Sv "Call”. NIDNTT 1: 271-6.

Das, A A 2001. Paul, the Law, and the Covenant. Peabody: Hendrickson Publishers.

Deidun, T J 1981. New Covenant Morality in Paul. Rome: Biblical Institute Press.

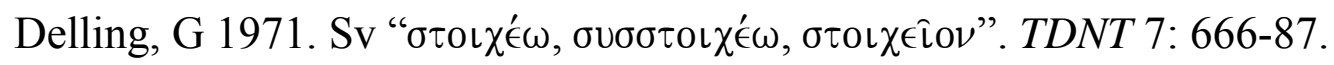

Dockery, D S 1993. Sv "Fruit of the Spirit". DPL: 316-9. 
Dunn, J D G 1993. A Commentary on The Epistle to the Galatians. London: A \& C Black.

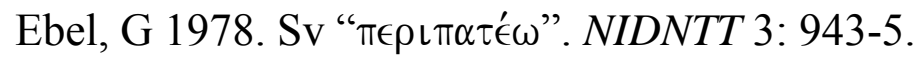

Esler, P F 1998. Galatians. London: Routledge.

Fee, G D 1994. "Freedom and the Life of Obedience (Galatians 5:1-6:18)," RExp. 91: 201-17.

Gärtner, B 1978. Sv “Suffer”. NIDNTT 2: 719-26.

Grundmann, W 1964. Sv “ $\alpha \mu \alpha \rho \tau \alpha \dot{\alpha} \nu \omega, \dot{\alpha} \mu \alpha \dot{\rho} \tau \tau \eta \mu \alpha, \dot{\alpha} \mu \alpha \rho \tau \dot{\imath} \alpha$ ”. TDNT 2: 339-42.

Guthrie, D 1981. New Testament Theology. Leicester: IVP.

Hansen, G W 1997. "Paul's Conversion and His Ethic of Freedom in Galatians." in RN Longenecker (ed), The Road From Damascus: The Impact of Paul's Conversion on His Life, Thought and Ministry. Cambridge: Eerdmans, 213-37.

-, 1999. "Resurrection and the Christian Life in Paul's Letters," in RN Longenecker (ed), Life in the Face of Death. The Resurrection Message of the New Testament. Grand Rapids: Eerdmans, 203-224.

Hays, R B 1983. The faith of Jesus Christ: An Investigation of the Substructure of Paul's Theology in Galatians 3:1-4:11. Chico: Scholars.

Helfmeyer, F J 1977. Sv “הָרָרך". TWAT 2: 415-33.

Hensel, R 1975. Sv “к $\alpha \rho \pi \varsigma_{\varsigma}$ ". NIDNTT 1: 721-3.

Houlden, J L 1992. Ethics and the New Testament. Edinburgh: T \& T Clark.

Jones, F S 1987. "Freiheit" in den Briefen des Apostels Paulus. Eine Historische, Exegetische und Religionsgeschichtliche Studie. Göttingen: Vandenhoeck \& Ruprecht.

Klappert, B 1976. Sv “King, Kingdom”. NIDNTT 2: 372-90.

Klauck, H J 2003. The Religious Context of Early Christianity: A Guide to the Graeco-Roman Religions. Minneapolis: Fortress.

Liddell, H G \& R Scott 1975. An Intermediate Greek-English Lexicon. Oxford: Clarendon.

Longenecker, R N 1990. Galatians. Dallas: Word.

-, 1994. “Graphic Illustrations of a Believer's New Life in Christ: Galatians 4:21-31,” RExp. 91: 183-99.

Loubser, J A 1994. "The Contrast Slavery/Freedom as Persuasive device in Galatians," Neotestamentica 28: 163-76.

Lull, D J 1980. The Spirit in Galatia. Paul's Interpretation of Pneuma as Divine Power. Chico: Scholars.

Martyn, J L 1996. "The Crucial Event in the History of Law (Gal 5:14)," in E $\mathrm{H}$ Lovering \& J L Sumney (eds), Theology and Ethics in Paul and His Interpreters. Nashville: Abingdon, 48-61. 
Marxsen, W 1993. New Testament Foundations for Christian Ethics. Minneapolis, Fortress.

Matera, F J 1996. New Testament Ethics. The Legacies of Jesus and Paul. Louisville: Westminister - John Knox.

Morris, L 1996. Galatians: Paul's Charter of Christian Freedom. Leicester: IVP.

Moule, C F D 1953. An Idiom Book of New Testament Greek. Cambridge:, Cambridge University Press.

Pretorius, E A C 1992. "The Opposition ПNEYMA and $\Sigma$ AP $\Xi$ as Persuasive Summons", Neotestamentica 26: 441-60.

Sanders, E P 1977. Paul and Palistinian Judaism. A Comparison of Patterns of Religion. London: SCM.

-, 1983. Paul, the Law and the Jewish People. Minnesota: Fortress.

Schmidt, K L 1965. Sv “k $\alpha \lambda \epsilon \omega$ ”. TDNT 3: 487-91.

Schreiner, T R 2001. Paul, Apostle of God's Glory in Christ: A Pauline Theology. Leicester: Apollos.

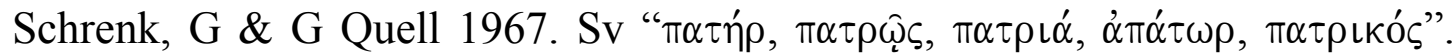
TDNT 5: 945-1022.

Thielman, F S 1989. From Plight to Solution. A Jewish Framework for Understanding Paul's View of the Law in Galatians and Romans. Leiden: E J Brill.

Westerholm, S 1997. "Sinai as Viewed from Damascus: Paul's Re-evaluation of the Mosaic Law" in R N Longenecker (ed), The Road From Damascus: The Impact of Paul's Conversion on His Life, Thought and Ministry. Cambridge: Eerdmans, 147-65.

Witherington, B 1998. Grace in Galatia: A Commentary on Paul's Letter to the Galatians. Grand Rapids: Eerdmans. 